\title{
Local radon flux maxima in the quaternary sediments of Schleswig-Holstein (Germany)
}

\author{
Johannes Albert $^{1}{ }^{\mathbb{C}} \cdot$ Maximilian Schärf $^{1} \cdot$ Frieder Enzmann $^{1} \cdot$ Martin Walt| $^{2} \cdot$ Frank Sirocko $^{1}$
}

Received: 2 July 2020 / Accepted: 11 March 2021 / Published online: 23 April 2021

(c) The Author(s) 2021

\begin{abstract}
This paper presents radon flux profiles from four regions in Schleswig-Holstein (Northern Germany). Three of these regions are located over deep-rooted tectonic faults or salt diapirs and one is in an area without any tectonic or halokinetic activity, but with steep topography. Contrary to recently published studies on spatial patterns of soil radon gas concentration we measured flux of radon from soil into the atmosphere. All radon devices of each profile were deployed simultaneously to avoid inconsistencies due to strong diurnal variations of radon exhalation. To compare data from different seasons, values had to be normalized. Observed radon flux patterns are apparently related to the mineralogical composition of the Quaternary strata (particularly to the abundance of reddish granite and porphyry), and its grain size (with a flux maximum in well-sorted sand/ silt). Minimum radon flux occurs above non-permeable, clay-rich soil layers. Small amounts of water content in the pore space increase radon flux, whereas excessive water content lessens it. Peak flux values, however, are observed over a deep-rooted fault system on the eastern side of Lake Plön, i.e., at the boundary of the Eastholstein Platform and the Eastholstein Trough. Furthermore, high radon flux values are observed in two regions associated with salt diapirism and near-surface halokinetic faults. These regions show frequent local radon flux maxima, which indicate that the uppermost strata above salt diapirs are very inhomogeneous. Deep-rooted increased permeability (effective radon flux depth) or just the boundaries between permeable and impermeable strata appear to concentrate radon flux. In summary, our radon flux profiles are in accordance with the published evidence of low radon concentrations in the "normal" soils of Schleswig-Holstein. However, very high values of radon flux are likely to occur at distinct locations near salt diapirism at depth, boundaries between permeable and impermeable strata, and finally at the tectonically active flanks of the North German Basin.
\end{abstract}

Keywords Radon flux $\cdot$ Local radon flux maxima $\cdot$ Permeability $\cdot$ Quaternary sediments $\cdot$ Salt tectonics $\cdot$ SchleswigHolstein

\section{Introduction}

The classification of so-called radon risk areas in Germany based on soil gas radon measurements combined with geological and soil investigations was first introduced by Kemski et al. (e.g., 1996,2001,2005). In more recent years, the "Bundesamt für Strahlenschutz" (2020) commissioned the establishment of a radon potential map for Germany to determine the health risk posed by radon nationwide based

Johannes Albert

jalber01@uni-mainz.de

1 Department for Geoscience, Johannes-Gutenberg University, J.-J.- Becher Weg 21, 55128 Mainz, Germany

2 RadonTec GmbH, Hauptstraße 5, 89426 Wittislingen, Germany on approximately 5,000 measuring points throughout Germany. Due to the passing of a new Radiation Protection Act in July 2017, the federated state of Schleswig-Holstein released a statewide radon potential map at the end of 2020 (Ministerium für Energiewende, Landwirtschaft, Umwelt, Natur und Digitalisierung 2020).

To validate the connection between tectonically and halokinetically active structures and locally elevated flux of radon, we studied radon flux and sediment properties in four research areas in Schleswig-Holstein, Northern Germany (Figs. 1, 2, 3, 4, 5, 6, 7). The uppermost strata in Northern Germany are mainly characterized by unconsolidated sediments accumulated during the Middle and Late Pleistocene glaciations (Böse et al. 2012; Ehlers et al 2004, 2011). Beneath these Quaternary deposits, Tertiary silts and sands are intruded by rising salt structures with 


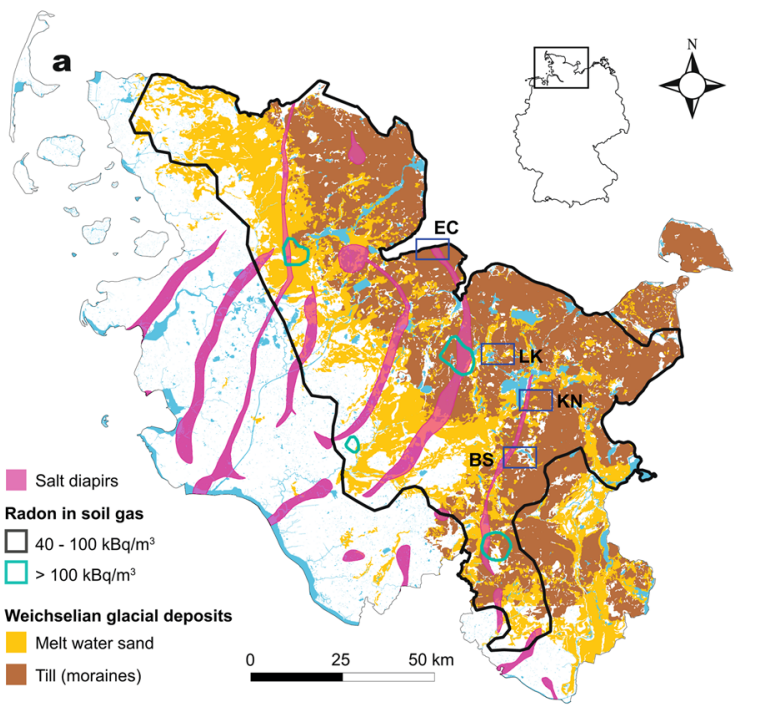

Fig. 1 Simplified overview of Schleswig-Holstein including loca-

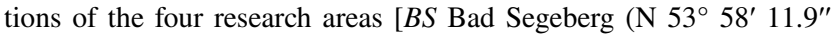
E $10^{\circ} 23^{\prime} 45.6^{\prime \prime}$ ), EC Eckernförde (N 54 ${ }^{\circ} 28^{\prime} 21.1^{\prime \prime}$ E $10^{\circ} 05^{\prime} 04.6^{\prime \prime}$ ),

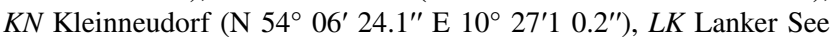
(N 54 $12^{\prime} 38.4^{\prime \prime}$ E $\left.10^{\circ} 19^{\prime} 06.9^{\prime \prime}\right)$ ]. a Spatial patterns of salt diapirs, distribution of Weichselian glacial deposits (https://www.umwel tdaten.landsh.de/nuis/upool/gesamt/geologie/guek250_gesamt.

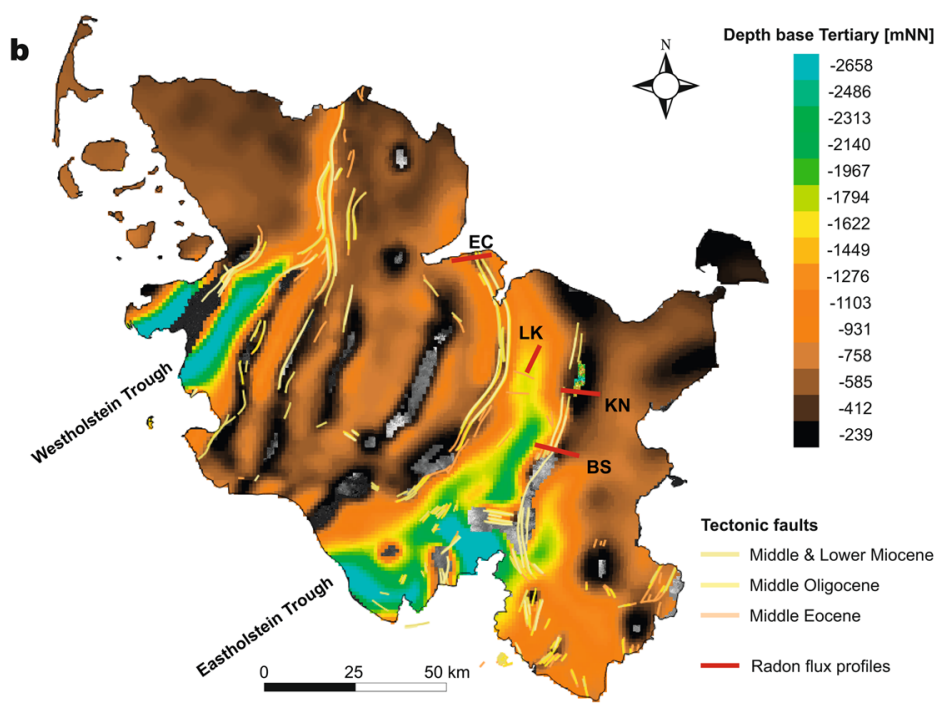

pdf Accessed 02 January 2021) and elevated radon in soil gas levels (https://www.bfs.de/DE/themen/ion/umwelt/radon/karten/boden Accessed 02 January 2021). b Depth of base Tertiary along with alignment of Tertiary tectonic faults and orientation of sampled radon profiles (after Geotektonischer Atlas von Nordwestdeutschland und dem deutschen Nordsee-Sektor 2001)

progeny radionuclide of ${ }^{226} \mathrm{Ra}$ (radium) and thus part of the ${ }^{238} \mathrm{U}$ (uranium) decay series has a half-life of 3.82 days. ${ }^{220} \mathrm{Rn}$ (thoron) is part of the ${ }^{232} \mathrm{Th}$ (thorium) decay chain and ${ }^{219} \mathrm{Rn}$ (actinon) is part of the ${ }^{235} \mathrm{U}$ series. Both have a very short half-life (55 s and $4 \mathrm{~s}$, respectively). Because of its main source being bedrock and soil (Turekian and Graustein 2003), radon is ubiquitous in the environment and therefore of great interest to understand its behavior in soil-air exchange processes.

Radon is a known cause for lung cancer and is responsible for thousands of deaths in Germany per year (Beck 2017; Menzler et al. 2008). It has been the subject of many scientific studies in many parts of Europe (Bundesamt für Strahlenschutz 2019; George 2008; Kreienbrock et al. 2001; UNSCEAR 1982) and radon risk maps have been established for many countries, including Germany (e.g., Bundesamt für Strahlenschutz 2020; Kemski et al. 1996, 2001, 2005), Spain (Sainz Fernández et al. 2017), and Switzerland (Kropat et al. 2017). Furthermore, radon is used as a footprint for natural phenomena associated with soil degassing along active faults and fractures (e.g., Chen et al. 2018; Iovine et al. 2018; Künze et al. 2012, 2013; Sciarra et al. 2018), and as a precursor for volcanic activities (e.g., Giammanco et al. 2009; Neri et al. 2016) and earthquakes (e.g. Richon et al. 2003; Steinitz et al. 2003; Woith 2015).

Radon gas is produced through alpha decay of radium within a mineral grain, but due to recoil effects only atoms originating near the grain boundary can escape and may

ring isotopes. The most common isotope ${ }^{222} \mathrm{Rn}$ (radon), 
emanate into the free pore space (Semkow 1990). Due to its relatively short half-life, radon can only migrate up to a few meters in the geosphere. So generally, its primary sources are the radium nuclides present in the surrounding bedrock, groundwater and soil. Furthermore, the emanation power is strongly dependent on grain size because of its short recoil range of about 20-70 nm (Breitner et al. 2010; Monnin and Seidel 1992). A smaller grain size increases the specific surface area and therefore amplifies the chance of radon atoms to leave the mineral grain. A further influence on radon emanation is moisture content, as water is a natural absorber of kinetic energy and impedes radon atoms from reaching their maximum recoil distances. Several studies revealed that, up to a certain water content, radon emanation enhances with increasing moisture on the grain surface (e.g., Hassan et al. 2009; Strong and Levins 1982; Yang et al. 2019), but radon is kept in groundwater until released by a temperature rise or drop of air pressure.

After leaving the mineral grain the gas migrates via two mechanisms, either through diffusion within the pore fluid or advection in the open pore space (Nazaroff 1992; Tanner 1964, 1980). These processes are dependent on concentration and pressure gradients, respectively. Diffusive mechanisms are usually in the order of $10^{-4}$ to $10^{-2} \mathrm{~m}$ per day and are therefore negligible for radon migration. Buoyant gas bubble movement and pressure- and densitydriven gas phase flux in the order of $10^{0}$ to $10^{3} \mathrm{~m}$ per day or higher may account for the main gas migration mechanisms (Etiope and Martinelli 2002). Migration distance via convection is strongly controlled by soil porosity and permeability. However, the quantity of radon in the subsurface is too insignificant to migrate by convection on its own, but radon atoms can be transported by a carrier, either in gaseous or liquid form to ensure greater transport distances (Etiope and Lombardi 1995). The most common carriers in the subsurface are $\mathrm{CH}_{4}$ and $\mathrm{CO}_{2}$, whose migration behaviors along tectonically active pathways are well understood (Irwin and Barnes 1980; Sciarra et al. 2018). With a half-life of less than 4 days and short migration distances, most of the radon produced decays near its formation. Thus, only radon atoms which originate near-surface, or are transported in permeable strata by a carrier gas from greater depths can reach the geosphere-atmosphere boundary and exhale into the atmosphere and disperse (Hassan et al. 2009), or accumulate indoors in inhabited areas (Finne et al. 2019).

Radon exhalation can vary greatly depending on time of day (Schubert and Schulz 2002; Tareen et al. 2019), season (Winkler et al. 2001), or even greater timescales. Yan et al. (2017) found a distinct connection between quasi-decadal (8-11 years) fluctuations of radon concentration sampled at a hot spring site in Southwestern China and variations in the spring's discharge rate and water temperature. Mudelsee et al. (2020) present a first radon flux time series from our research site Kleinneudorf and document different modes of radon release from the subsurface, predominantly dependent on atmospheric pressure and air temperature variations.

\section{Regional geology}

Schleswig-Holstein is the northernmost federated state of Germany (Fig. 1). It borders Denmark to the north and the North Sea to the west. To the south, the Elbe River marks the borderline to the adjacent federated states of Niedersachsen and Hamburg. To the east, Mecklenburg-Vorpommern as well as the Baltic Sea border the state.

Geologically, the research areas belong to the North German Basin which itself is part of the much larger Central European Basin System, a NW-SE trending tectonic structure stretching from Norway to Central Germany and from the North Sea to Poland (Bayer et al. 1999; Littke et al. 2008). Hundreds of meters of salt were deposited in this basin during the Permian and are today overlain by up to $10 \mathrm{~km}$ of Mesozoic and Cenozoic strata. This results in a massive overload causing the salt to react ductile, leading to the rise of salt diapirs and associated fault systems that can reach up to the surface (Fig. 1). The salt can even penetrate the surface, as in Bad Segeberg.

The initial salt movement started during the Triassic, although two other major phases of diapirism occurred during the Jurassic and Cenozoic (Maystrenko et al. 2005). Several studies even show that these halokinetic processes are still active until present day (Al Hseinat et al. 2016; Al Hseinat and Hübscher 2017; Lehné and Sirocko 2005, 2010; Sirocko et al. 2002, 2008).

The topography of Schleswig-Holstein was shaped by three glacial advances (Saalian, Elsterian, and Weichselian glaciations), that transported moraine material from Scandinavia and deposited it in Northern Germany in form of alternating sequences of glacial till and glaciofluvial sands. The result is a landscape with elevated moraines, valleys and abundant lakes (Böse et al. 2012; Ehlers et al. 2004, 2011).

\section{Research areas}

The areas for our radon flux sampling were chosen according to the pattern of salt diapirs and known halokinetic faults, documented in the "Geotektonischer Atlas von Nordwestdeutschland und dem deutschen Nordsee-Sektor" (2001; Fig. 1). We chose research areas where information from the deeper strata was accessible from seismic surveys, which reveal tectonic structures in the topmost $500 \mathrm{~m}$. This ensures the presence of permeable faults, that extend into the Quaternary sediments with a potential to reach the surface (Wiederhold et al. 2003; Al Hseinat et al. 2016). The 
modern topography of Schleswig-Holstein is available as a GIS-computed grid (https://www.schleswig-holstein.de/DE/ Landesregierung/LVERMGEOSH/Service/serviceGeobasis daten/geodatenService_Geobasisdaten_Dienste).

The research area Lanker See (LK) is located in direct proximity east of Lake Lanker and extends in $\mathrm{N}-\mathrm{S}$ direction across several, partially forested or farmed ridges and valleys (Fig. 3). The region lies between two salt walls where the "Geotektonischer Atlas von Nordwestdeutschland und dem deutschen Nordsee-Sektor" (2001) documents a complete absence of faults at depth (Fig. 1). This area was chosen to study the influence of topography on radon flux and to gain information about typical radon background levels in Schleswig-Holstein.

The sampling site Kleinneudorf (KN) lies $2 \mathrm{~km}$ east of Lake Plön (Figs. 1, 4a). The tectonic feature specific to this area is an actively subsiding depression on the lake's eastern shore near the village of Kleinneudorf located on the flank of a salt diapir. Its topographic changes have been described by Lehné and Sirocko $(2005,2010)$ and Sirocko et al. (2002, 2008). Several independent eyewitnesses have reported visual changes to the characteristic landscape of the site over the last 50 years. The area is located directly above the contact zone between the Eastholstein Platform to the east and the flank of the Eastholstein Trough beneath the lake (Fig. 4c). The associated faults strike in $\mathrm{N}-\mathrm{S}$ direction parallel to the lake's shoreline (Geotektonischer Atlas von Nordwestdeutschland und dem deutschen Nordsee-Sektor 2001) and appear to cause local subsidence of $\mathrm{cm} / \mathrm{a}$, which is unusually high for Northern Germany, but still comparable to local subsidence rates, for example in the city of Lüneburg, southeast of Hamburg (Sirocko 2012).

The third research area is Bad Segeberg (BS), located around $6.2 \mathrm{~km}$ northeast of the Kalkberg, a prominent salt dome in the city of Bad Segeberg (Fig. 5a). In the vicinity to the chosen sampling profiles lies the Segeberg-Sülberg salt wall, a N-S striking, about 50-km long salt structure mainly consisting of Zechstein salt (Fig. 1). Ross (1998) reports recent uplift rates for the Kalkberg of about $0.5 \mathrm{~mm} / \mathrm{a}$, whereas other authors suggest uplift rates of up to $1.2 \mathrm{~mm} / \mathrm{a}$ (Meier 2003). The sampling site is near the village of Wardersee directly south of Lake Warder and crosses a suspected border fault outcrop (Wiederhold et al. 2003; Fig. 5b). The measured profiles roughly include sampling points of Künze et al. (2013) who conducted part of their research on radon in soil gas concentration in this area.

The fourth sampling area (EC) stretches along the Eckernförde Bay shoreline, about $15 \mathrm{~km}$ east of the city of Eckernförde (Figs. 1, 6a). The measured sections extend from the village of Lindhöft in the west to Dänisch-Nienhof in the east. A salt structure and several associated deep-rooted faults extend in $\mathrm{N}-\mathrm{S}$ direction perpendicular to the shoreline (Al Hseinat et al. 2016; Fig. 6c).

\section{Methods}

All data were generated during field campaigns in 2018 and 2019 (Table 1). We measured radon with up to 16 devices simultaneously. This setup does not measure soil radon content but monitors the flux from the soil into the air, providing composite information on processes related not only to the primary radon content of the soil, but also its permeability, and thus depth of active radon convection in the groundwater unsaturated zone of the surface strata.

\section{Sampling strategy to measure radon flux}

Sampling was performed with a commercial radon concentration measuring device (Radona Expert+, modified by RadonTec $\mathrm{GmbH}$ ). The display of the instrument was modified to show concentration values of radon every ten minutes. In addition to measuring radon concentration and temperature, the instrument records the prevailing humidity and atmospheric pressure.

The Radona system was mounted on an aluminum ring of $14 \mathrm{~cm}$ in diameter. Before measurement, the topmost soil layer $0-20 \mathrm{~cm}$ was removed. The aluminum ring of the device was pushed about $2 \mathrm{~cm}$ into the soil to allow gas from the subsurface to migrate through, but minimize the effects of wind entering the detection chamber (Figs. 2a, b). Initial and end concentrations after $2 \mathrm{~h}$, expressed as $\mathrm{Bq} / \mathrm{m}^{3}$, were determined and the differences between the readings are presented as flux values. If values were significant already after $1 \mathrm{~h}$, we stopped measurements to not exceed the detection limit of the devices. In consideration of daily variability of radon activity (Mudelsee et al. 2020; Schubert and Schulz 2002; Tareen et al. 2019), all sampling
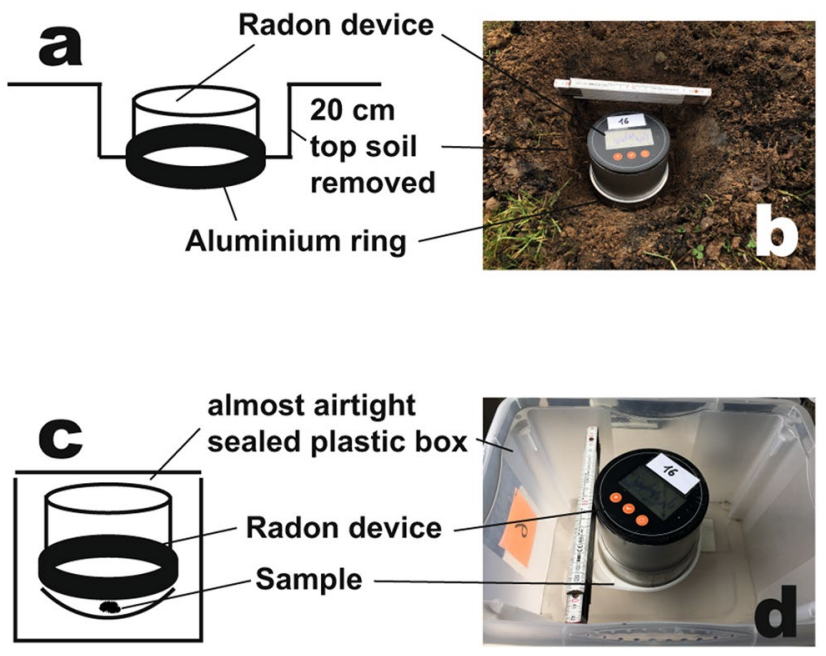

Fig. 2 Illustration of sampling setup. a Schematic description and b picture of radon flux field sampling. c Schematic description and d picture of radon sampling under laboratory conditions. Figure d shows setup prior to attachment of lid 


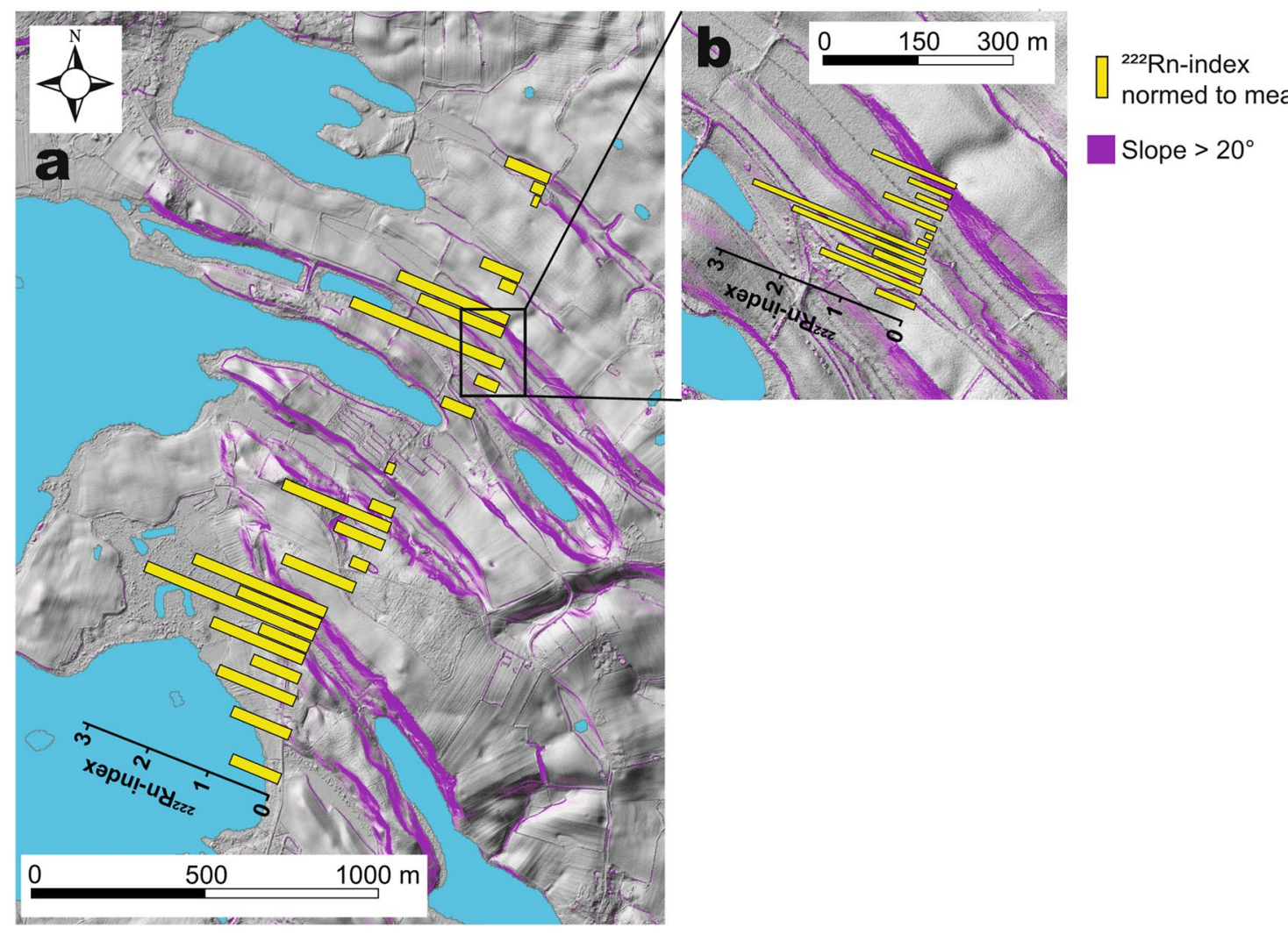

Fig. 3 Study site Lanker See (LK; N 54 $12^{\prime} 38.4^{\prime \prime}$ E $\left.10^{\circ} 19^{\prime} 06.9^{\prime \prime}\right)$. a ${ }^{222}$ Rn-indices of profile across several small ridges near Lake Lanker. b Area of interest at a small flatland in the northeastern part of the research area

points of a single profile were measured with as little time offset as possible, depending on number of research assistants and distances between individual sampling points. According to Tuccimei and Soligo (2008), high $\mathrm{CO}_{2}$ concentrations can interfere with radon flux signals. However, ongoing studies show that $\mathrm{CO}_{2}$ levels in Schleswig-Holstein lie well below these critical levels and we therefore did not include a correction factor for interfering $\mathrm{CO}_{2}$ into our data. In addition to radon flux values, the prevailing meteorological conditions were recorded (Table 1) and sediment physical properties were calculated (Fig. 7).

Measured radon data were converted into conventional flux values $\left(\mathrm{mBq} / \mathrm{m}^{2} \mathrm{~s}\right)$ using the formula described by Perrier et al. (2009). Our flux values cannot be used to define "Radon Risk Areas" (https://www.bfs.de), but facilitate to distinguish regional and local anomalies in the flow of radon from soil to air. The advantage of this method is to detect the strength of degassing without any drilling effort. To ensure comparability between our own profiles measured at different days and seasons, radon values were normalized through division to mean radon flux of respective profiles to obtain synthesized ${ }^{222} \mathrm{Rn}$-indices. We chose this approach because absolute values are arbitrary and depend on time of measurement. Normalized values, however, are comparable to each other and provide a fast and easy approach to detect local gas exhalation anomalies over large regions at different times.

\section{Radon devices}

The measurement principle of the Radona device is based on an ionization chamber with a volume of $218.8 \mathrm{~cm}^{3}$, where an electric field is applied between an enclosure (cathode) and an inner electrode needle (anode). The positively charged alpha particles, which are formed within the chamber during the decay of radon and its progeny isotope polonium, ionize the air in the measuring chamber. This charged air is accelerated towards the anode or cathode and causes minimal temporal changes to the electrical field, that are detected and evaluated as radioactive decay. As humidity and vibrations of the electrode needle cause similar changes within the electric field, very high humidity or increased vibrations disturb the signal and can lead to failure of the sensor. The Radona device has an application range of $0.2-3700 \mathrm{~Bq} / \mathrm{m}^{3}$ and a measuring accuracy of $\pm 5-10 \%$, depending on weather conditions. The efficiency for radon sampling specified by the 
manufacturer is 0.5 counts per minute (cpm) at $1 \mathrm{pCi} / 1$, or, equivalently, a "harmonized" efficiency of $81 \mathrm{cph}$ at $100 \mathrm{~Bq} /$ $\mathrm{m}^{3}$. The operating range of the device chamber is $10-40{ }^{\circ} \mathrm{C}$. However, the chamber is still functional at $0{ }^{\circ} \mathrm{C}$, because temperature is not a primary factor for the reliability of the chamber. Although temperatures below $10^{\circ} \mathrm{C}$ might slightly increase the measurement error, the impact of this effect is minimal and neglectable for our specific sampling strategy.

\section{Radon flux transects}

Gas flux profiles consist of up to 16 sampling points (16 Radona devices) on transects perpendicular to faults visible in seismic profiles or the "Geotektonischer Atlas von Nordwestdeutschland und dem deutschen Nordsee-Sektor"
(2001). Fault lines were projected vertically to the earth's surface using the information of the "Geotektonischer Atlas" (Figs. 4, 5, 6). For profiles with more than 16 sampling points (see Table 1), sampling was performed on 2 separate days and measured radon flux values of the second day were normalized to the results of the first day at two points of sampling. Transects were of 1-2 km length to guarantee a sufficient distance to the center area above fault outcrops. To ensure higher resolution in zones of elevated radon exhalation, sampling distance was reduced near points of apparent high radon activity. Additionally, we conducted more detailed surveys in areas of interest with lengths of a few hundred meters. Individual sampling points were selected after accessibility to the area and soil cover.
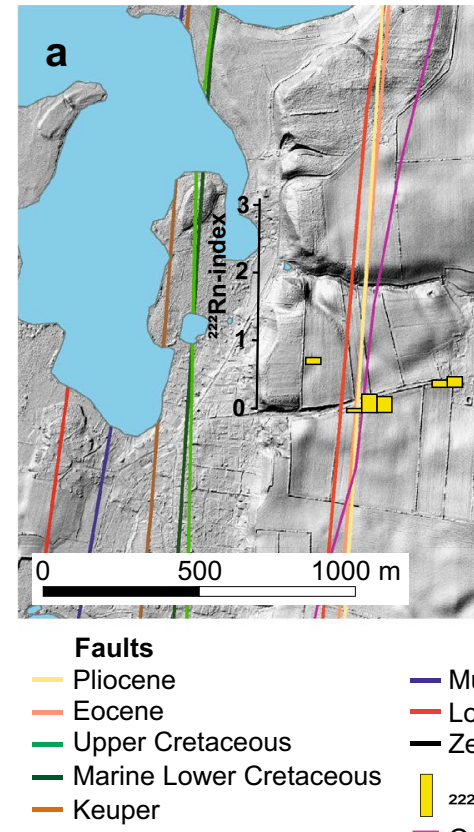

\section{C}

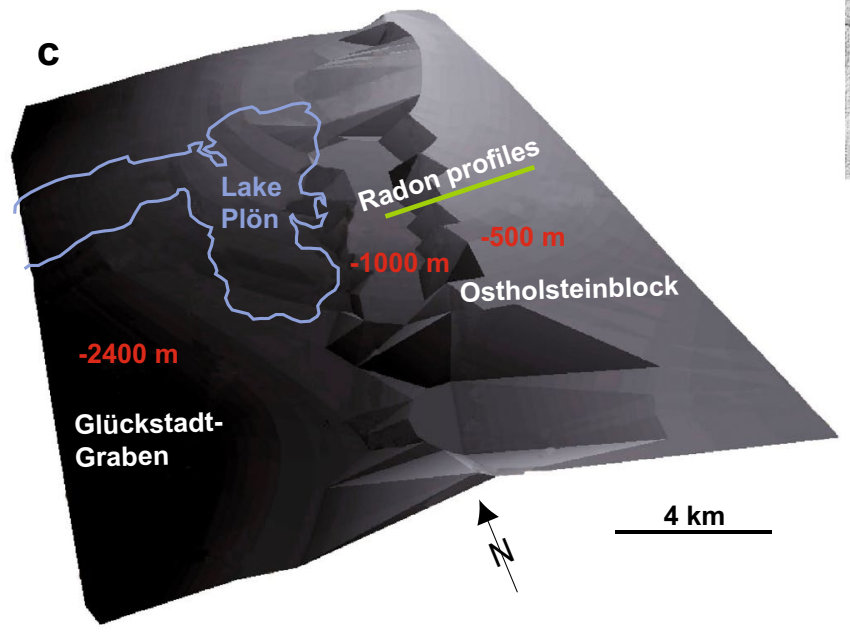

- Muschelkalk
— Lower and Middle Buntsandstein - Zechstein

${ }^{222} \mathrm{Rn}$-index normed to mean $\square$ Outline salt dome
Fig. 4 Study site Kleinneudorf (KN; N 54 $06^{\prime} 24.1^{\prime \prime}$ E $\left.10^{\circ} 27^{\prime} 10.2^{\prime \prime}\right)$. $\mathbf{a}^{222}$ Rn-indices of profiles across the actively sinking depression. b ${ }^{222}$ Rnindices of profiles through the depression itself. c 3D-Model of the base Upper Cretaceous in the area of Lake Plön (after Sirocko et al. 2008) 


\section{Soil samples}

Soil samples were collected along selected profiles using a steel tube of known volume. Samples were taken exactly beneath the location of the radon instruments and weighted to calculate wet bulk density. Subsequently, samples were dried in an oven at $55{ }^{\circ} \mathrm{C}$ for several hours to remove moisture content without altering soil chemistry (e.g., organic carbon content) and, after cooling, weighted again to determine water content and dry bulk density. Mean grain sizes were identified using a Camsizer particle analyzer by "Retsch Technology". Permeability coefficients $\left(k_{\mathrm{f}}\right)$ were calculated using the empirical formulas of Beyer (1964) and Seiler (1973), which are based on grain size compositions of samples. To isolate the clay fraction from the silt fraction, the Atterberg experimental method was used (Stein 1985). The loss-on-ignition (LOI) method was applied to determine organic carbon content (Dean 1974). For this purpose, specimens were weighted, heated at $550{ }^{\circ} \mathrm{C}$ for $4 \mathrm{~h}$ inside a
"Nabertherm" muffle furnace and weighted again to obtain LOI values, which mainly represent organic carbon. Carbonate content was analyzed using the gas volumetric Scheibler method described by Tatzber et al. (2007).

\section{Results}

\section{Radon flux transects}

From March 2018 till August 2019, a total of 22 radon profiles (323 sampling points) were measured. Profiles for all research areas are summarized in Table 1 and Fig. 7. The temperature ranged from $3.1{ }^{\circ} \mathrm{C}$ in March to $23.2{ }^{\circ} \mathrm{C}$ in August. Atmospheric pressure varied between 997.7 and $1023.7 \mathrm{hPa}$ and relative humidity between 51 and $89 \%$. Water content of soil samples varies between 2.49 and 50.97 wt\% (Fig. 7a). Bulk density wet and bulk density dry range from 0.75 to $1.93 \mathrm{~g} / \mathrm{cm}^{3}$ (Fig. $7 \mathrm{~b}$ ) and from 0.53 to

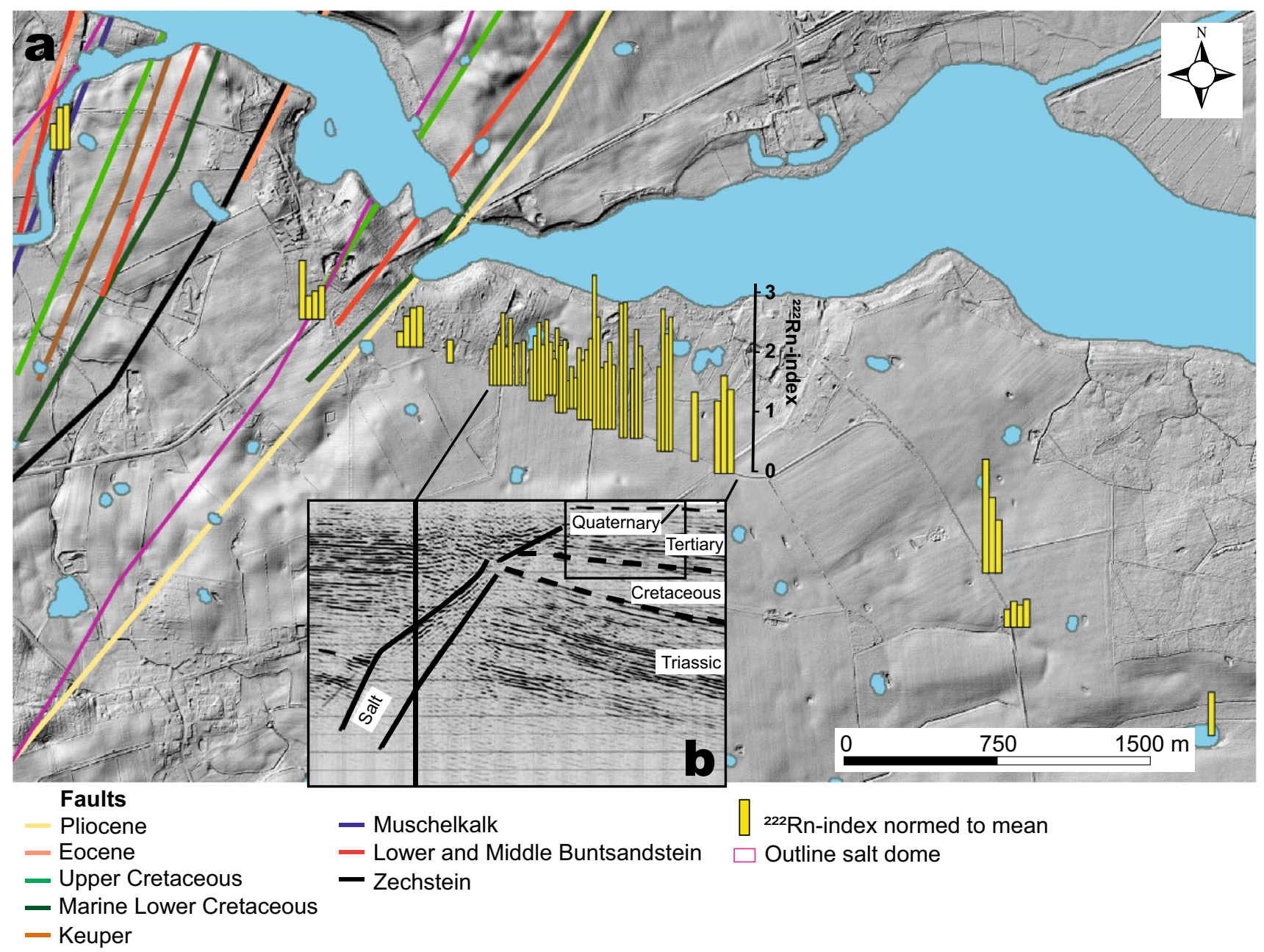

Fig. 5 Study site Bad Segeberg (BS; N 53 58 $11.9^{\prime \prime}$ E $10^{\circ} 23^{\prime} 45.6^{\prime \prime}$ ). a ${ }^{222}$ Rn-indices of profiles across border fault outcrop. b Seismic profile adapted from Wiederhold et al. (2003) 
$1.66 \mathrm{~g} / \mathrm{cm}^{3}$ (Fig. 7c), respectively. Mean grain sizes vary between 145 and $729 \mu \mathrm{m}$ (Fig. 7d). Permeability coefficients $\left(k_{\mathrm{f}}\right)$ range from 1.83E-06 to $7.12 \mathrm{E}-04 \mathrm{~m} / \mathrm{s}$ (Seiler; Fig. 7e) and from $1.47 \mathrm{E}-06$ to $2.48 \mathrm{E}-04 \mathrm{~m} / \mathrm{s}$ (Bayer; Fig. 7f). LOI varies between 0.67 and $18.67 \mathrm{wt} \%$ (Fig. $7 \mathrm{~g}$ ) and calcium carbonate content between 0 and $1.15 \mathrm{wt} \%$ (Fig. 7h).

In the research area Lanker See (LK) mean radon flux was $1.41 \mathrm{mBq} / \mathrm{m}^{2} \mathrm{~s}$ for profile LK1 (Table 1). Maximum radon exhalation occurred at two sites, which are at the slope toe of the southernmost margin $\left({ }^{222} \mathrm{Rn}\right.$-indices between 2.14 and 2.73) and at the slopes bordering a small flatland in the northern part of the area $\left({ }^{222} \mathrm{Rn}\right.$-indices between 1.36 and 2.46; Fig. 3a). A more detailed profile (LK2) was sampled across the flatland and showed mean radon flux of $2.87 \mathrm{mBq} /$ $\mathrm{m}^{2} \mathrm{~s}$. Maximum radon flux was observed at the southern, rather smooth slope $\left({ }^{222} \mathrm{Rn}\right.$-indices between 1.91 and 2.67) and minimal radon exhalation occurred at the lowermost part of the flatland $\left({ }^{222} \mathrm{Rn}\right.$-indices between 0.11 and 0.21 ; Fig. 3b).

In the research area Kleinneudorf $(\mathrm{KN})$ mean radon flux ranged from 0.65 to $4.01 \mathrm{mBq} / \mathrm{m}^{2} \mathrm{~s}$ for all profiles (Table 1). Maximum radon exhalation was detected within the sinking depression and on the neighbouring farmlands $\left({ }^{222} \mathrm{Rn}\right.$-indices between 2.90 and 5.32; Fig. 4a). At higher spatial resolution through the depression, peak radon flux occurred at the steep flanks of the trough ${ }^{222} \mathrm{Rn}$-indices between 2.88 and 6.63; Fig. 4b).

In Bad Segeberg (BS) mean radon flux was between 1.03 and $2.58 \mathrm{mBq} / \mathrm{m}^{2} \mathrm{~s}$ (Table 1). Maximum radon activity was recorded about 0.93 to $1.15 \mathrm{~km}$ east of the salt dome above a suspected border fault outcrop $\left({ }^{222} \mathrm{Rn}\right.$-indices between 1.52 and 2.35; Fig. 5a). The tectonic faults above the salt dip with an angle of $35^{\circ}$. We have plotted these faults at the depth of Tertiary strata. The extension to the surface will shift their position to the east into the region of the radon flux maxima (Fig. 5b).

In Eckernförde (EC) mean flux values ranged from 1.48 to $2.12 \mathrm{mBq} / \mathrm{m}^{2} \mathrm{~s}$ for all profiles (Table 1). We measured increased radon flux levels in the vicinity to the fault zone ${ }^{222} \mathrm{Rn}$-indices between 2.07 and 3.93; Fig. 6a). Two detailed traverses at the fault zone's eastern margin showed maximum radon exhalation at the southern, steep slope with ${ }^{222} \mathrm{Rn}$-indices of 5.05 (EC7) and 3.69 (EC8), quite contrary to the trough base and its northern flank (Fig. 6b).

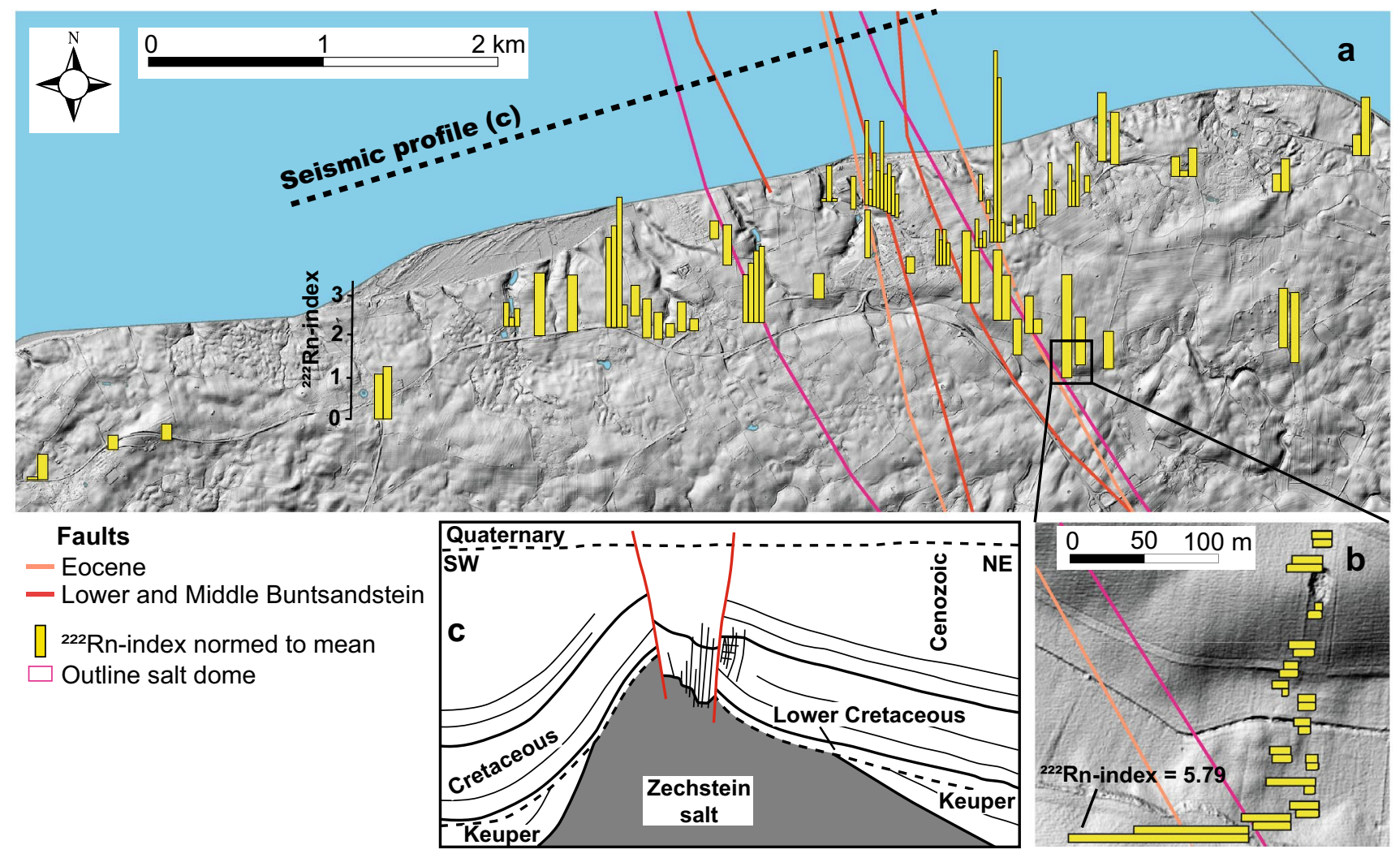

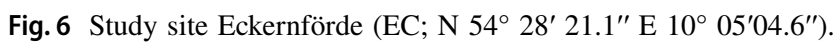
a ${ }^{222} \mathrm{Rn}$-indices of profiles across the fault zone parallel to the Eckernförde Bay. b Area of interest through a small trough in the south- ern part of the research area. c Schematic description of the subsurface, adapted from Al Hseinat (2016) 


\section{Exhalation depth}

Due to radon concentration being significantly higher between 0.7 and $1 \mathrm{~m}$ than in shallower depths (Künze et al. 2013; Rose et al. 1990), we compared the radon flux sig$\mathrm{nal}$ at the surface and from a $1 \mathrm{~m}$ deep drilling hole for our specific sampling strategy at seven sampling points. We used the setup described in the sampling strategy chapter to measure radon flux at the surface. To obtain information about flux levels at greater depths, we drilled boreholes using a hand-operated drilling implement. We then inserted a plastic filter pipe with slits along its complete length into each borehole, which increases the actively degassing soil area, refilled the space between the pipe and the drill hole wall with the excavation material and connected the pipe to the measuring device.

Although absolute values are not comparable between the surface and 1-m depth for our sampling strategy, which is due to the increased soil area inside the borehole, radon flux was two/three times higher for the 1-m depth measurements. It is most likely the enlargement of actively degassing soil volume that causes an increase of flux out of the borehole. Therefore, active exhalation depth is an important factor to determine radon flux. This appears to us as the most probable explanation for increased radon flux above faults. Permeable faults not only transport gas from greater depths to the surface, but also from an enlarged soil area along the fault.

However, it is significantly labour-consuming to drill an adequate amount of boreholes for an interpretable profile. For identifying anomalies of enhanced radon flux it is sufficient to remove only the top soil, as long as all sampling points are prepared uniformly and grain size distributions of soils and soil types are comparable between measurement sites. A method to determine the precise influence of the exhalation depth has not yet been developed, but will be the subject of a future, systematic study.

\section{Laboratory experiments}

We measured radon emanation powers of selected samples in the laboratory for (1) typical tillitic material occurring in Schleswig-Holstein and (2) various other natural substances

Table 1 Overview of surveys carried out including prevailing meteorological condition during time of sampling

\begin{tabular}{|c|c|c|c|c|c|c|c|c|c|}
\hline Name & Date & Profile length & Sampl. points & $\begin{array}{l}\text { Sampl. } \\
\text { time (h) }\end{array}$ & $\begin{array}{l}\text { Mean }{ }^{222} \mathrm{Rn} \text { flux } \\
\left(\mathrm{mBq} / \mathrm{m}^{2} \mathrm{~s}\right)\end{array}$ & $\begin{array}{l}\text { Highest }^{222} \\
\text { Rn-Idx }\end{array}$ & $\begin{array}{l}\text { Temp. } \\
\left({ }^{\circ} \mathrm{C}\right)\end{array}$ & $\begin{array}{l}\text { Atm. press. } \\
(\mathrm{hPa})\end{array}$ & $\begin{array}{l}\text { Air moist. } \\
(\%)\end{array}$ \\
\hline \multicolumn{10}{|c|}{ Bad Segeberg } \\
\hline BS1 & 4 Apr 2019 & $3.37 \mathrm{~km}$ & 13 & 2 & 1.71 & 2.24 & 13.9 & 997.7 & 60 \\
\hline BS2 & 16 July 2019 & $3.69 \mathrm{~km}$ & 13 & 2 & 2.58 & 2.32 & 19.5 & 1012.0 & 60 \\
\hline BS3 & 16 July 2019 & $3.69 \mathrm{~km}$ & 11 & 2 & 2.04 & 1.78 & 17.5 & 1013.0 & 67 \\
\hline BS4 & 17 July 2019 & $3.69 \mathrm{~km}$ & 13 & 2 & 2.09 & 2.00 & 15.7 & 1013.9 & 77 \\
\hline BS5 & 14 Aug 2018 & $495 \mathrm{~m}$ & 14 & 1 & 1.03 & 2.35 & 23.2 & 1007.0 & 65 \\
\hline BS6 & 3 Apr 2019 & $495 \mathrm{~m}$ & 16 & 2 & 2.39 & 1.52 & 10.8 & 1002.5 & 89 \\
\hline \multicolumn{10}{|c|}{ Eckernförde } \\
\hline EC1 & 8 Apr 2019 & $11.76 \mathrm{~km}$ & 16 & 2 & 2.00 & 3.93 & 8.1 & 1011.8 & 65 \\
\hline $\mathrm{EC} 2$ & 9 Apr 2019 & $4.70 \mathrm{~km}$ & 16 & 2 & 2.02 & 3.89 & 5.5 & 1015.7 & 51 \\
\hline $\mathrm{EC} 3$ & 17 July 2019 & $11.76 \mathrm{~km}$ & 14 & 2 & 1.89 & 2.45 & 18.6 & 1010.9 & 72 \\
\hline $\mathrm{EC} 4$ & 18 July 2019 & $4.89 \mathrm{~km}$ & 14 & 2 & 1.48 & 2.13 & 18.2 & 1009.4 & 77 \\
\hline EC5 & 18 July 2019 & $2.79 \mathrm{~km}$ & 14 & 2 & 1.50 & 2.50 & 19.1 & 1007.9 & 77 \\
\hline $\mathrm{EC}$ & 19 July 2019 & $10.17 \mathrm{~km}$ & 14 & 2 & 2.12 & 2.07 & 19.9 & 1009.4 & 78 \\
\hline EC7 & 19 July 2019 & $263 \mathrm{~m}$ & 14 & 2 & 1.56 & 5.05 & 20.3 & 1010.5 & 71 \\
\hline EC8 & 20 July 2019 & $263 \mathrm{~m}$ & 14 & 2 & 1.51 & 3.69 & 22.9 & 1008.9 & 56 \\
\hline \multicolumn{10}{|c|}{ Kleinneudorf } \\
\hline KN1 & 23 Mar 2018 & $2.45 \mathrm{~km}$ & 11 & 1 & 0.65 & 5.32 & 3.1 & 1007.0 & 85 \\
\hline KN2 & 5 Apr 2019 & $2.35 \mathrm{~km}$ & 16 & 2 & 2.71 & 2.90 & 9.9 & 1005.6 & 81 \\
\hline $\mathrm{KN} 3$ & $6 \& 10$ Apr 2019 & $2.91 \mathrm{~km}$ & 19 & 1 & 4.01 & 3.91 & 12.8 & 1008.4 & 69 \\
\hline $\mathrm{KN}$ & 21 Mar 2018 & $198 \mathrm{~m}$ & 13 & 1 & 0.72 & 5.20 & 4.9 & 1023.7 & 75 \\
\hline KN5 & 22 Mar 2018 & $161 \mathrm{~m}$ & 13 & 1 & 1.18 & 6.36 & 5.6 & 1008.2 & 89 \\
\hline KN6 & 7 Apr 2019 & $103 \mathrm{~m}$ & 16 & 2 & 2.73 & 2.88 & 9.5 & 1009.6 & 73 \\
\hline \multicolumn{10}{|c|}{ Lanker See } \\
\hline LK1 & $7 \& 8$ Aug 2019 & $2.57 \mathrm{~km}$ & 25 & 2 & 1.41 & 2.73 & 18.8 & 1004.9 & 81 \\
\hline LK2 & 9 Aug 2019 & $221 \mathrm{~m}$ & 14 & 2 & 2.87 & 2.67 & 20.3 & 1011.2 & 69 \\
\hline
\end{tabular}



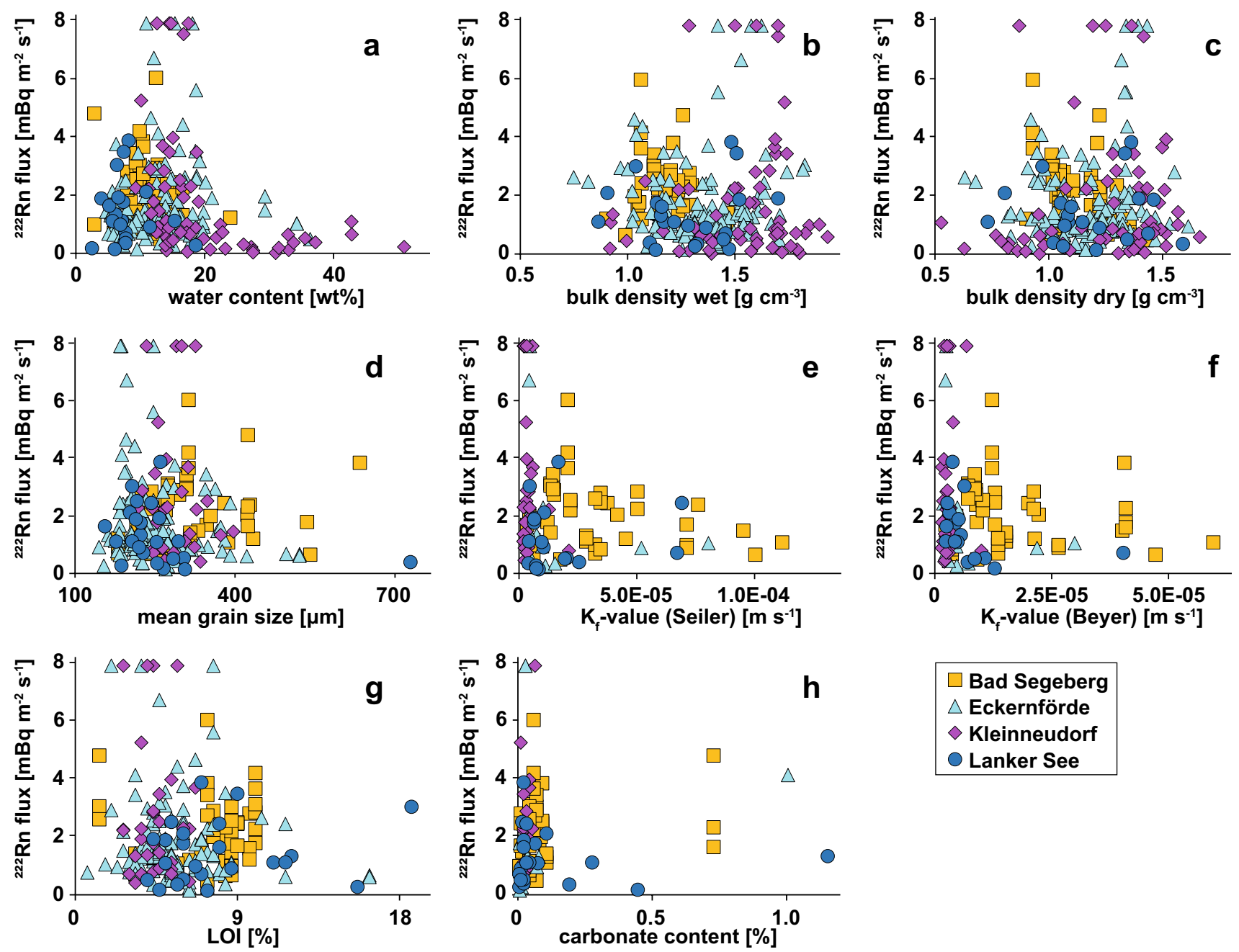

Fig. 7 Measured radon flux compared to a water content, $\mathbf{b}$ bulk density wet, $\mathbf{c}$ bulk density dry, $\mathbf{d}$ mean grain size, e permeability coefficient after Seiler, $\mathbf{f}$ permeability coefficient after Beyer, $\mathbf{g}$ Loss on
Ignition (LOI), and $\mathbf{h}$ carbonate content of soil samples. Shown sample points may exceed detection limit of $7.85 \mathrm{mBq} / \mathrm{m}^{2} \mathrm{~s}$ to support our acquired field results (Fig. 8). In total, radon emanation power for 52 sediment samples (silt-sand fraction) of uniform weight (100 g) were analyzed using the Radona system in almost airtight sealed plastic boxes, to still allow air to enter and gently disperse the accumulating radon (Fig. 2c, d). Sampling time for all specimens was $1 \mathrm{~h}$. The technical error of the device is $\pm 10 \%$. To minimize additional reproduction errors, we have considered an error of $\pm 40 \%$ to be significant. It was found that differences in emanation values greater than $50 \%$ for the various materials were indeed reproducible. However, obtained absolute values depend on our specific sampling setup (measured quantities, duration of sampling) and are thus not comparable to other studies. The results show very high radon production for primary red-colored, feldspar-rich granitic, porphyritic and gneissic materials (Fig. 8). All other samples show none to slightly elevated emanation levels compared to the surrounding air.

To gain information about grain size and water content dependence of radon emanation, we further measured radon emanation powers for a specific type of granite, the Götemar granite (originally from Sweden), at various grain sizes and moisture contents (Fig. 9). After being crushed and grinded, the material was separated into cobble, gravel, sand, silt, and clay fractions, which were then measured at different water contents using the above-mentioned sampling setup. The results present maximum production for the silt fraction. The sand and gravel size fraction certainly have a high permeability, but the total specific surface area $\left(\mathrm{m}^{2} / \mathrm{g}\right)$ of gravel grains is much lower than for silt, which combines high emanation power from a large specific surface with high permeability. If water is added to the variable 


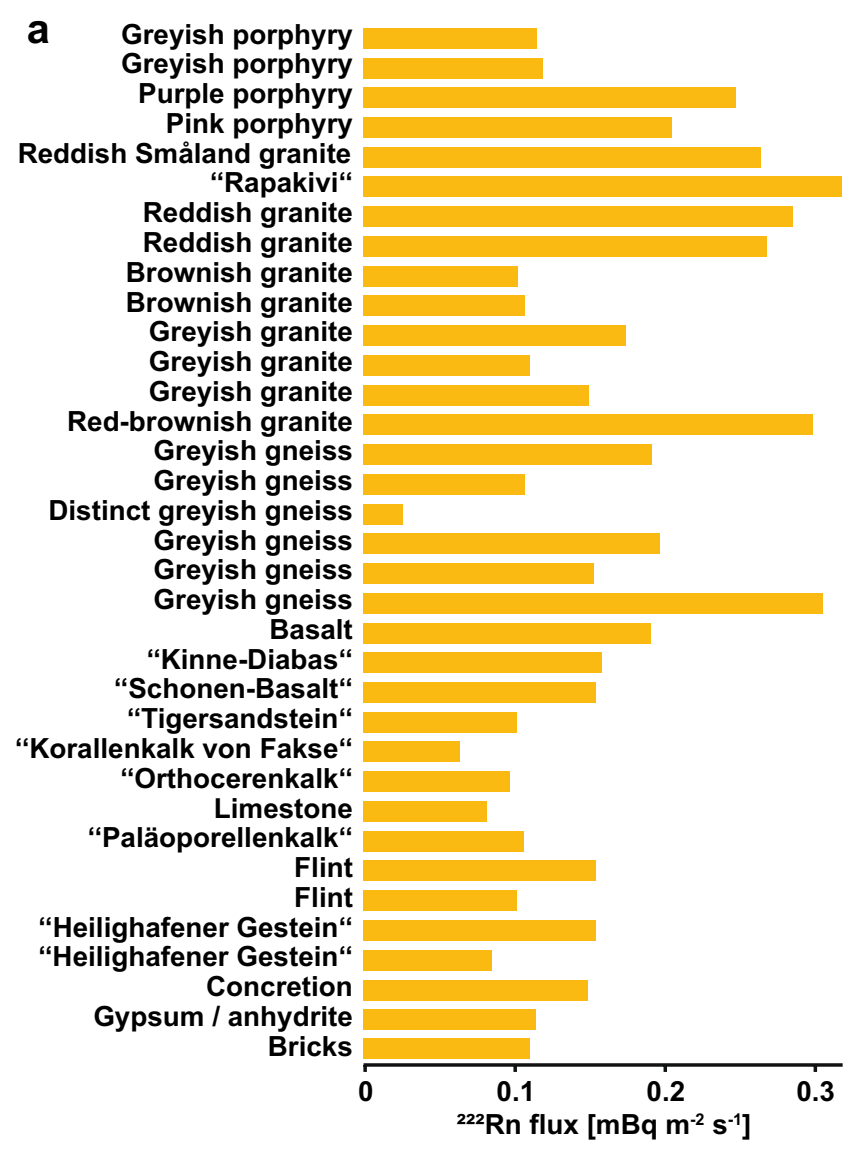

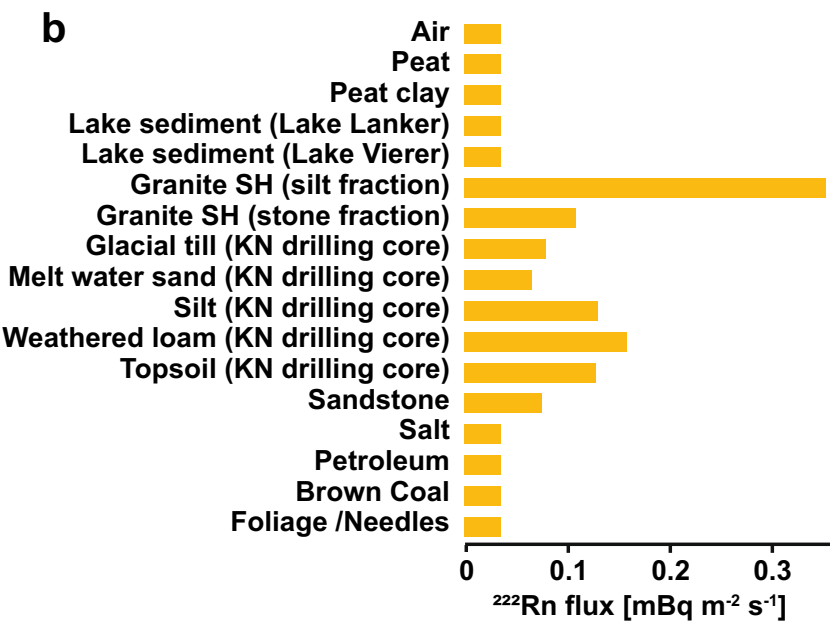

Fig. 8 Radon emanation power of a typical tillitic material occurring in Schleswig-Holstein and b various other natural substances

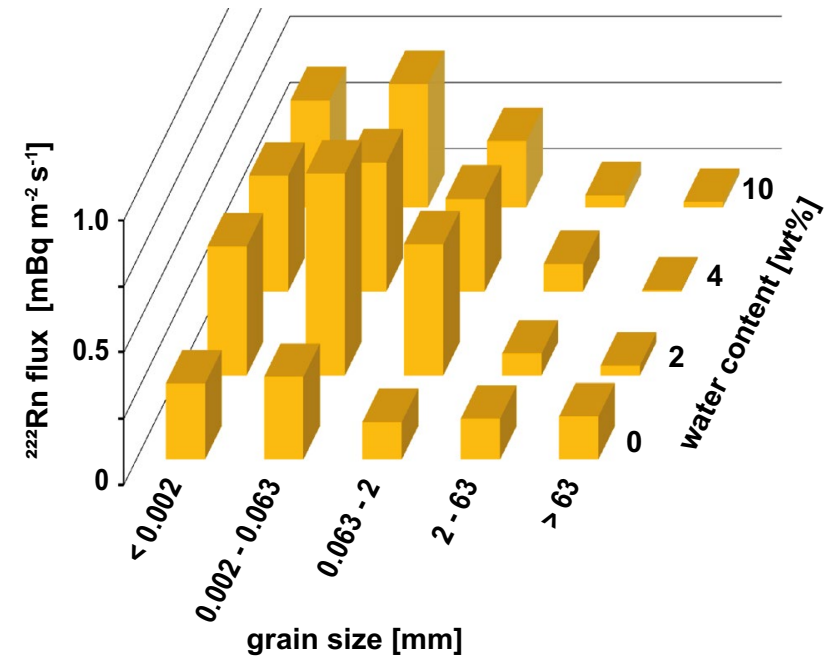

Fig. 9 Radon emanation power of the Leitgeschiebe (indicator stone) "Götemar granite" (from Sweden) at various grain sizes and water contents system, radon release is significantly higher for wet samples compared to dry samples for fractions smaller than $2 \mathrm{~mm}$. Maximum radon emanation is reached for the silt fraction at $2 \mathrm{wt} \%$ water content.

Increased permeability in well-sorted sand and silt may allow a general high gas flow in glacial melt water sands. A slight wetness of the strata could even intensify the radon flux when these water films evaporate (Fig. 9). Water coatings of mineral grains slow down emanating radon atoms, preventing them from entering adjacent grains and keeping them in the covering pore water. Ongoing studies are designed to show that this proportion could then be released if the sediment is heated or if changes in air pressure modify the storing capacity of the water "film". These convective processes operate only in the unsaturated zone, but not when the pore space is filled with pore water (saturated zone). Apparently, radon is more effectively released if the open pore space facilitates gas flux. Contrarily, excessive moisture content would be conducive to the compaction of the soil due to water surface tension and thereby lessen the emanation power (Tanner 1980). 


\section{Local radon flux maxima (LRFM)}

We could not identify any strong connection between increased radon flux and physical properties of the soil samples (Fig. 7). Radon anomalies cannot be explained by sediment properties directly beneath single points of sampling and must therefore be of different origin. We identify various processes, which can cause LRFM. Figure 10 presents a schematic model of potential sources for anomalously high radon flux.

We found in experiments under laboratory conditions elevated emanation levels for feldspar-rich, reddish granites, porphyria and gneisses compared to other samples (Fig. 8). Sedimentary structures of radium-rich sands/silts can lead to an increased radon emanation potential compared to the surrounding areas (Mineralogical LRFM; Fig. 10).

Near Lake Lanker, we measured radon activity in soil gas in an area with no known active fault system, i.e., an area where we can expect typical radon background flux in Schleswig-Holstein, which is strongly influenced by the radium-rich sediments of Weichselian tills (see above). However, the radon flux was not homogenous. Increased exhalation appears to occur at sampling points near contact zones to water-saturated, clay-rich, impermeable sediment deposits (Sedimentary LRFM; Figs. 3b, 10).

Highest flux values were detected above tectonic and halokinetic fault systems and can be regarded as an indicator of actively rising gas at the fault, caused by increased permeability. This deep-rooted flux results in an anomaly linked to structural deformations of the subsurface (Structural LRFM; Fig. 10). Highest radon flux signals are not limited to areas directly above fault outcrops, but may be scattered in the loose sediment packages overlying these fault systems (Figs. 4, 5, 6).

In Kleinneudorf, we found maximum radon flux levels in the unconsolidated sediments above a deep-rooted fault system caused by the displacement between the Eastholstein Platform and the Eastholstein Trough (Fig. 4). A 40-m deep drilling core and seismic surveys of the Kleinneudorf depression document a loose sediment package below this depression between 30 and 40 m (Köhn et al. 2019; Rabbel et al. in prep; Sirocko et al. in prep.).

Near the Segeberg-Sülberg salt dome, we measured a sudden increase in radon flux directly above the outcrop of a border fault (Fig. 5a). From there, a halokinetic LRFM with values up to 2.5 times higher than their respective means stretches for a few hundred meters eastward, explainable by the low angle of faults and thus a shifted penetration point (Fig. 5b). These results are coherent with the study of Künze et al. (2013), who conducted soil gas analysis across the same border fault and found a similar distribution of increased radon concentrations in soil gas.
We further found zones of maximum radon activity linked to active halokinetic fault structures near the shoreline of the Eckernförde Bay, where halokinetic LRFMs form perpendicular to the shore along the fault's outcrops or in their close vicinity (Fig. 6).

\section{Discussion}

Gas exhalation varies greatly depending on time of day or season (e.g., Tareen et al. 2019; Winkler et al. 2001) and environmental factors, such as temperature and air pressure, strongly control outgassing cycles (Mudelsee et al. 2020). For the majority of our sampling points, radon flux does not exceed $5 \mathrm{mBq} / \mathrm{m}^{2} \mathrm{~s}$ (Fig. 7). We interpret these values as typical radon background activity in Schleswig-Holstein, which agrees well with the radon flux map of Europe by Karstens et al. (2015), who estimated similar flux levels based on soil properties, uranium content and modelled soil moisture contents derived from two different reanalysis data sets.

By establishing the radon potential map for Germany, Kemski et al. (e.g., 2001,2005) showed that elevated radon background activity in the eastern part of Schleswig-Holstein is contributed to the mineralogical composition of the subsurface, more precisely to the sediments of the Weichselian glaciers which cover large areas of the state (Fig. 1). This glacial material mainly consists of potassium bearing granitic and porphyry deposits, rich in parent radionuclides, showing increased levels of radon emanation (Fig. 8). Birke et al. (2009) detected increased uranium concentrations for these glacial sediments and therefore sufficient source material for radioactive decay to occur. As shown in Fig. 1, regions of increased radon background levels coincide with the distribution of radium-rich glacial deposits.

Even if the mineralogical composition of the subsurface is relatively homogenous over large areas, radon flux is characterized by considerable spatial variations. Clay-rich soil layers in valley depths with water-saturated pore space act as a natural plug for soil gas release (Tanner 1980), which deviates the rising radon gas to the flanks of the impermeable strata and causes high radon flux at the boundary of the clay-rich strata (Figs. 3b, 10).

Maximum radon flux is observed in the vicinity of active fault outcrops (Figs. 4, 5, 6), indicating an enrichment of radon activity in connection with zones of deep reaching high permeability. Areas above active fault systems do not necessarily have to exhibit enhanced radon in soil gas, but are more likely to show increased levels of radon exhalation. This is not only given above open faults associated with thermal wells or $\mathrm{CO}_{2}$ fumaroles, but also in regions of strong surface subsidence, which leads to a loose sedimentary structure. It is quite likely that the exhalation depth in Kleinneudorf reaches well into these highly permeable cover 


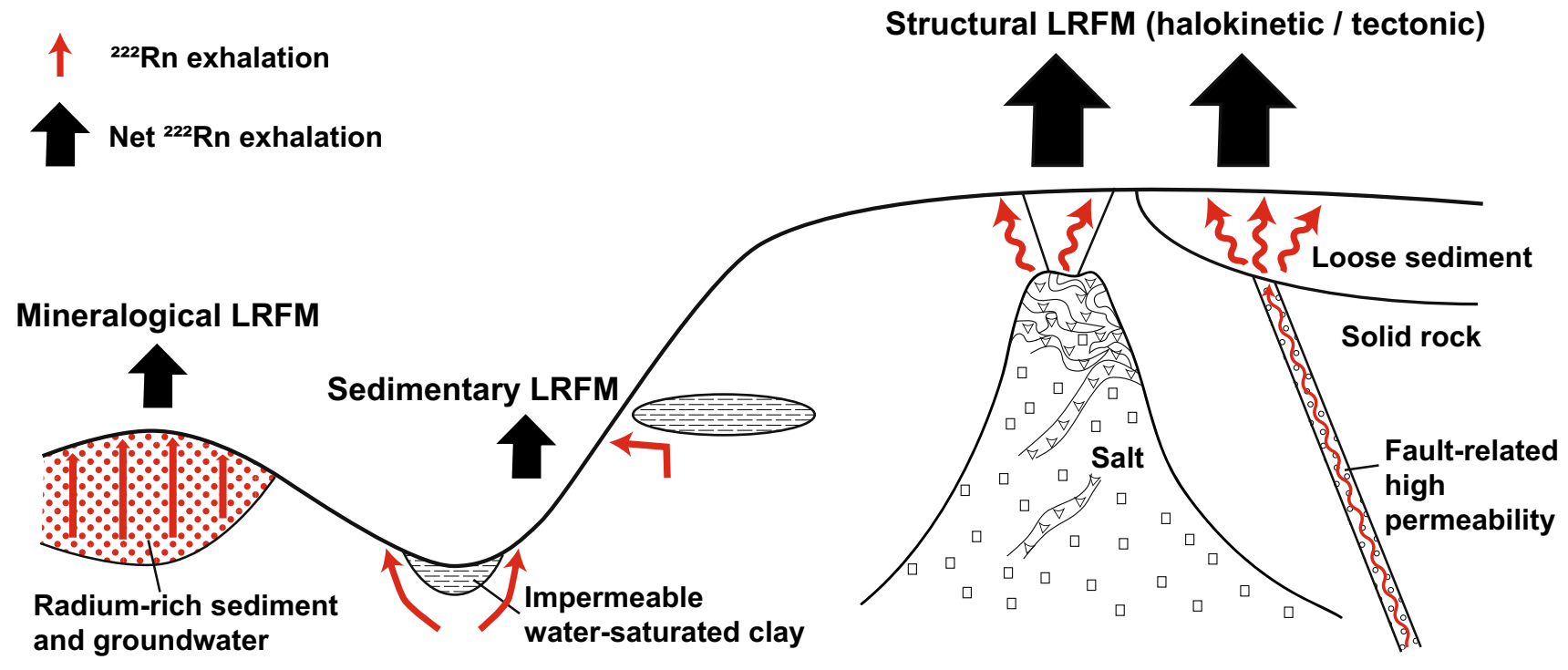

Fig. 10 Schematic description of possible sources for different types of local radon flux maxima (LRFM). Size of black arrows indicates relative net quantity of radon exhalation

sands, which are formed by gravitational sinking of the cover sediments above a deep-rooted tectonic fault (Fig. 10).

The subsurface of Schleswig-Holstein is characterized by several vast salt walls and accompanying fault structures (Fig. 1), along which potential LRFM can form. The influence of this process must depend on the depth and uplift activity of the salt. In Bad Segeberg, the salt reaches the surface, whereas in other locations the top of salt diapirs can be several hundred meters deep. If the rise of salt was strong enough to create keystone fault structures (as in Eckernförde), the halokinetic process is sufficient to produce advective pathways for deep-rooted radon migration.

Increased radon activity in connection with structural pathways can be observed worldwide. Iovine et al. (2018) found a strong connection between increased radon in soil gas and active tectonic structures in the Calabrian Arc in Southern Italy. Künze et al (2012) measured similar anomalous radon signals above both seismically active and inactive fault systems in the Cantabrian Mountains in Northwest Spain. Since it has a half-life of only 3.82 days, radon originating in depths of a few hundred meters or more cannot reach the surface unless it uses the presence of a carrier. Chyi et al. (2010) showed in experimental studies that an induced $\mathrm{CO}_{2}$ flux lead to anomalously high radon signals. Since $\mathrm{CO}_{2}$ is an abundant component of soil gases and is able to cover great distances by advection, it can transport radon atoms upwards from a deeper source to soil cover along active fault structures (Perrier et al. 2009; Sciarra et al. 2018). Ongoing research is designed to compare the outgassing cycles of radon and $\mathrm{CO}_{2}$ in Schleswig-Holstein in long time series and study the role of $\mathrm{CO}_{2}$ as a possible carrier gas for radon in that region.

\section{Conclusions}

In this work we present a rapid, yet reliable method for measuring radon flux from soil to atmosphere. We conducted our research in four geologically unique locations in Schleswig-Holstein and conclude that there is a distinct connection between the presence of active fault structures and increased radon flux. Even though absolute radon values differ considerably between measuring campaigns, socalled LRFM can, but do not have to form in close vicinity to suspected fault outcrops. Furthermore, the mineralogical composition of the subsurface, in particular the abundance of reddish Scandinavian granites, and contact zones between permeable and impermeable soil layers can create radon flux anomalies. Although, the resulting radon exhalation does not reach quantitative or spatial dimensions like flux levels caused by increased permeability through faulting activity. In summary, the following LRFM types, classified into three geological categories, can be distinguished (Fig. 10):

- Mineralogical LRFM, strongly affected by the accumulation of radionuclide-rich sediment deposits,

- Sedimentary LRFM, influenced by diverted migration paths due to clay-rich, impermeable soil layers, 
- Structural (tectonic/halokinetic) LRFM, forming in areas of deep reaching structural pathways due to tectonic and/ or halokinetic activity.

Supplementary Information The online version contains supplementary material available at https://doi.org/10.1007/s00531-021-02026-8.

Acknowledgements We thank the numerous students, who participated in the field campaigns in 2017-2019 and helped with the radon flux measurements and soil sampling.

Author contributions JA, MS and FS were responsible for radon measurements and processing the data. FE contributed the GIS processed maps and RW adjusted the radon sensors to our specific needs.

Funding Open Access funding enabled and organized by Projekt DEAL. This research, which is part of the ANGUS II (Auswirkungen der Nutzung des geologischen Untergrundes als thermischer, elektrischer oder stofflicher Speicher) project, was funded by the German "Bundesministerium für Wirtschaft und Energie (BMWi)".

Availability of data and material All tables will be available in electronic form as supplementary information and will be downloadable at our university website (https://www.klimaundsedimente.geowissens chaften.uni-mainz.de).

\section{Declarations}

Conflict of interest This manuscript has not been published and is not under consideration for publication elsewhere.

Open Access This article is licensed under a Creative Commons Attribution 4.0 International License, which permits use, sharing, adaptation, distribution and reproduction in any medium or format, as long as you give appropriate credit to the original author(s) and the source, provide a link to the Creative Commons licence, and indicate if changes were made. The images or other third party material in this article are included in the article's Creative Commons licence, unless indicated otherwise in a credit line to the material. If material is not included in the article's Creative Commons licence and your intended use is not permitted by statutory regulation or exceeds the permitted use, you will need to obtain permission directly from the copyright holder. To view a copy of this licence, visit http://creativecommons.org/licenses/by/4.0/.

\section{References}

Al Hseinat M, Hübscher C (2017) Late Cretaceous to recent tectonic evolution of the North German Basin and the transition zone to the Baltic Shield/southwest Baltic Sea. Tectonophys 708:28-55. https://doi.org/10.1016/j.tecto.2017.04.021

Al Hseinat M, Hübscher C, Lang J, Lüdmann T, Ott I, Polom U (2016) Triassic to recent tectonic evolution of a crestal collapse graben above a salt-cored anticline in the Glückstadt Graben/North German Basin. Tectonophys 680:50-66. https://doi.org/10.1016/j. tecto.2016.05.008

Bayer U, Scheck M, Rabbel W, Krawczyk CM, Götze H-J, Stiller M, Beilecke T, Marotta A-M, Barrio-Alvers L, Kuder J (1999) An integrated study of the NE German Basin. Tectonophys
314(1-3):285-307. https://doi.org/10.1016/S0040-1951(99) $00249-8$

Beck TR (2017) (2017) Risks and radiation doses due to residential radon in Germany. Radiat Prot Dosim 175(4):466-472. https:// doi.org/10.1093/rpd/ncw374

Beyer W (1964) Zur Bestimmung der Wasserdurchlässigkeit von Kiesen und Sanden aus der Kornverteilungskurve. Wasserwirtsch Wassertech 14:165-169

Birke M, Rauch U, Lorenz H (2009) Uranium in stream and mineral water of the Federal Republic of Germany. Environ Geochem Health 31:693-703. https://doi.org/10.1007/s10653-009-9247-4

Böse M, Lüthgens C, Lee JR, Rose J (2012) Quaternary glaciations of northern Europe. Quat Sci Rev 44:1-25. https://doi.org/10.1016/j. quascirev.2012.04.017

Breitner D, Arvela H, Hellmuth KH, Renvall T (2010) Effect of moisture content on emanation at different grain size fractions-a pilot study on granitic esker sand sample. J Environ Radioact 101(11):1002-1006. https://doi.org/10.1016/j.jenvrad.2010.07. 008

Bundesamt für Strahlenschutz (2019) Radon-Handbuch Deutschland. https://www.bfs.de/SharedDocs/Downloads/BfS/DE/broschueren/ ion/radon-handbuch.pdf. Accessed 2 Jan 2021

Bundesamt für Strahlenschutz (2020) Karte Radon-Potential. https:// www.bfs.de/DE/themen/ion/umwelt/radon/karten/boden. Accessed 2 Jan 2021

Chen Z, Li Y, Liu Z, Wang J, Zhou X, Du J (2018) Radon emission from soil gases in the active fault zones in the Capital of China and its environmental effects. Sci Rep 8:1-12. https://doi.org/10. 1038/s41598-018-35262-1

Chyi LL, Quick TJ, Yang TF, Chen CH (2010) The experimental investigation of soil gas radon migration mechanisms and its implication in earthquake forecast. Geofluids 10(4):556-563. https://doi. org/10.1111/j.1468-8123.2010.00308.x

Dean WE (1974) Determination of carbonate and organic matter in calcareous sediments and sedimentary rocks by loss on ignition; comparison with other methods. J Sediment Petrol 44:242-248. https://doi.org/10.1306/74D729D2-2B21-11D7-8648000102 C1865D

Ehlers J, Eißmann L, Lippstreu L, Stephan H-J, Wansa S (2004) Pleistocene glaciations of North Germany. In: Ehlers J, Gibbard PL (eds) Quaternary glaciations-extent and chronology, part I: Europe, 1st edn. Elsevier, Amsterdam, pp 135-146

Ehlers J, Grube A, Stephan H-J, Wansa S (2011) Pleistocene glaciations of north Germany-new results. Dev Quat Sci 15:149162. https://doi.org/10.1016/B978-0-444-53447-7.00013-1

Etiope G, Lombardi S (1995) Evidence for radon transport by carrier gas through faulted clays in Italy. J Radioanal Nucl Chem 193(2):291-300. https://doi.org/10.1007/bf02039886

Etiope G, Martinelli G (2002) Migration of carrier and trace gases in the geosphere: an overview. Phys Earth Planet Inter 129(34):185-204. https://doi.org/10.1016/S0031-9201(01)00292-8

Finne IE, Kolstad T, Larsson M, Olsen B, Prendergast J, Rudjord AL (2019) Significant reduction in indoor radon in newly built houses. J Environ Radioact 196:259-263. https://doi.org/10. 1016/j.jenvrad.2018.01.013

George AC (2008) World history of radon research and measurement from the early 1900's to today. In: The natural radiation environment -8th international symposium, AIP conference proceedings 1034, Brazil, pp 20-33

Geotektonischer Atlas von Nordwest-Deutschland und dem deutschen Nordsee-Sektor (2001). In: Baldschuhn R, Binot F, Fleig S, Kockel F (eds) Geologisches Jahrbuch Reihe A, Band A 153. Schweizerbart'sche, Stuttgart

Giammanco S, Immè G, Mangano G, Morelli D, Neri M (2009) Comparison between different methodologies for detecting radon in soil along an active fault: The case of the Pernicana 
fault system, Mt. Etna (Italy). Appl Radiat Isot 67(1):178-185. https://doi.org/10.1016/j.apradiso.2008.09.007

Hassan NM, Hosoda M, Ishikawa T, Sorimachi A, Sashoo SK, Tokonami S, Fukushi M (2009) Radon migration process and its influence factors; review. Jpn J Health Phys 44:218-231. https:// doi.org/10.5453/jhps. 44.218

Iovine G, Guagliardi I, Bruno C, Greco R, Tallarico A, Falcone G, Lucà F, Buttafuoco G (2018) Soil-gas radon anomalies in three study areas of Central-Northern Calabria (Southern Italy). Nat Hazards 91:193-219. https://doi.org/10.1007/ s11069-017-2839-x

Irwin WP, Barnes I (1980) Tectonic relations of carbon dioxide discharges and earthquakes. J Geophys Res 85(B6):3115-3121. https://doi.org/10.1029/JB085iB06p03115

Karstens U, Schwingshackl C, Schmithüsen D, Levin I (2015) A process-based ${ }^{222} \mathrm{Rn}$ flux map for Europe and its comparison to long-term observations. Atmos Chem Phys 15(22):12845-12865. https://doi.org/10.5194/acp-15-12845-2015

Kemski J, Klingel R, Siehl A (1996) Classification and mapping of radon-affected areas in Germany. Environ Int 22:789-798. https:// doi.org/10.1016/S0160-4120(96)00185-7

Kemski J, Siehl A, Stegemann R, Valdivia-Manchego M (2001) Mapping the geogenic radon potential in Germany. Sci Total Environ 272:217-230. https://doi.org/10.1016/S0048-9697(01)00696-9

Kemski J, Klingel R, Siehl A, Stegemann R (2005) Radon transfer from ground to houses and prediction of indoor radon in Germany based on geological information. Radioact Environ 7:820-832. https://doi.org/10.1016/S1569-4860(04)07103-7

Köhn D, Thorwart M, De Nil D, Rabbel W, Sirocko F (2019) Charakterisierung einer Störungszone östlich des großen Plöner Sees (Schleswig Holstein) mittels 2D SH Full Waveform Inversion. In: 79th annual meeting of the German Geophysical Society, Braunschweig

Kreienbrock L, Kreuzer M, Gerken M, Dingerkus G, Wellmann J, Keller G, Wichmann HE (2001) Case-Control study on lung cancer and residential radon in Western Germany. Am J Epidemiol 153:42-52. https://doi.org/10.1093/aje/153.1.42

Kropat G, Bochud F, Murith C, Palacios M, Baechler S (2017) Modeling of geogenic radon in Switzerland based on ordered logistic regression. J Environ Radioact 166:376-381. https://doi.org/10. 1016/j.jenvrad.2016.06.007

Künze N, Koroleva M, Reuther CD (2012) ${ }^{222}$ Rn activity in soil gas across selected fault segments in the Cantabrian Mountains. NW Spain Radiat Meas 47(5):389-399. https://doi.org/10.1016/j. radmeas.2012.02.013

Künze N, Koroleva M, Reuther CD (2013) Soil gas ${ }^{222}$ Rn concentration in northern Germany and its relationship with geological subsurface structures. J Environ Radio 115:83-96. https://doi.org/10. 1016/j.jenvrad.2012.07.009

Lehné R, Sirocko F (2005) Quantification of recent movement potentials in Schleswig-Holstein (Germany) by GIS-based calculation of correlation coefficients. Int J Earth Sci 94:1094-1102. https:// doi.org/10.1007/s00531-005-0043-9

Lehné R, Sirocko F (2010) Recent vertical crustal movements and resulting surface deformation within the North German Basin (Schleswig-Holstein) derived by GIS-based analysis of repeated precise leveling data. Z Dtsch Ges Geowiss 162(2):175-188. https://doi.org/10.1127/1860-1804/2010/0161-0175

Littke R, Bayer U, Gajewski D, Nelskamp S (2008) Dynamics of complex intracontinental basins, 1st edn. Springer, Berlin. https://doi. org/10.1007/978-3-540-85085-4_2

Maystrenko Y, Bayer U, Scheck-Wenderoth M (2005) Structure and evolution of the Glueckstadt Graben due to salt movements. Int J Earth Sci (Geol Rundsch) 94:799-814. https://doi.org/10.1007/ s00531-005-0003-4
Meier G (2003) Ingenieurgeologische Ergebnisse bei der Standsicherheitsanalyse der „Kalkberghöhle“ in Bad Segeberg. Tagung f Ing.Geol 14, Kiel.

Menzler S, Piller G, Gruson M, Schaffrath-Rosario A, Wichmann HE, Kreienbrock L (2008) Population attributable fraction for lung cancer due to residential radon in Switzerland and Germany. Health Phys 95:179-189. https://doi.org/10.1097/01.HP.00003 09769.55126 .03

Ministerium für Energiewende, Landwirtschaft, Umwelt, Natur und Digitalisierung (2020) Pressemitteilung „Untersuchungsprogramm abgeschlossen: Radon-Belastung in Schleswig-Holstein liegt unterhalb der Schwellenwerte". https://www.schleswig-holst ein.de/DE/Landesregierung/V/Presse/PI/2020/1220/201207 Radon. Accessed 2 Jan 2021

Monnin MM, Seidel JL (1992) Radon in soil-air and in groundwater related to major geophysical events: a survey. Nucl Instrum Methods Phys Res A 314(2):316-330. https://doi.org/10.1016/ 0168-9002(92)90975-A

Mudelsee M, Albert J, Sirocko F (2020) Weather control in radon flux time series from Schleswig-Holstein. Germany Int J Geomath 11:23. https://doi.org/10.1007/s13137-020-00156-w

Nazaroff WW (1992) Radon transport from soil to air. Rev Geophys 30(2):137-160. https://doi.org/10.1029/92RG00055

Neri M, Ferrera E, Giammanco S, Currenti G, Cirrincione R, Patanè G, Zanon V (2016) Soil radon measurements as a potential tracer of tectonic and volcanic activity. Sci Rep 6:1-12. https://doi.org/ 10.1038/srep24581

Perrier F, Richon P, Byrdina S et al (2009) A direct evidence for high carbon dioxide and radon-222 discharge in Central Nepal. Earth Planet Sci Let 278(3-4):198-207. https://doi.org/10.1016/j.epsl. 2008.12.008

Richon P, Sabroux JC, Halbwachs M, Vandemeulebrouck J, Poussielgue N, Tabbagh J, Punongbayan R (2003) Radon anomaly in the soil of Taal volcano, the Philippines: a likely precursor of the $\mathrm{M}$ 7.1 Mindoro earthquake (1994). Geophys Res Lett 30(9):1-4. https://doi.org/10.1029/2003GL016902

Rose AW, Hutter AR, Washington JW (1990) Sampling variability of radon in soil gases. J Geochem Explor 38:173-191. https:// doi.org/10.1016/0375-6742(90)90100-O

Ross P-H (1998) Salzaufstieg und Geländemorphologie in Schleswig-Holstein-der Segeberger Salzstock und seine schutzwürdige Karstlandschaft. Jahrbuch für den Kreis Segeberg. C H Wäser, Bad Segeberg

Sainz Fernández S, Quindós Poncela LS, Fernández Villar A et al (2017) Spanish experience on the design of radon surveys based on the use of geogenic information. J Environ Radioact 166:390-397. https://doi.org/10.1016/j.jenvrad.2016.07.007

Schubert M, Schulz H (2002) Diurnal radon variations in the upper soil layers and at the soil-air interface related to meteorological parameters. Health Phys 83(1):91-96. https://doi.org/10.1097/ 00004032-200207000-00010

Sciarra A, Mazzini A, Inguaggiato S, Vita F, Lupi M, Hadi S (2018) Radon and carbon gas anomalies along the Watukosek Fault System and Lusi mud eruption, Indonesia. Mar Pet Geol 90:7790. https://doi.org/10.1016/j.marpetgeo.2017.09.031

Seiler KP (1973) Durchlässigkeit, Porosität und Kornverteilung quartärer Kies-Sand-Ablagerungen des bayerischen Alpenvorlandes. GWF Wasser Abwasser 114:353-400

Semkow TM (1990) Recoil-emanation theory applied to radon release from mineral grains. Geochim Cosmochim Acta 54(2):425-440. https://doi.org/10.1016/0016-7037(90)90331-E

Sirocko F (2012) Lüneburg und das Salz. www.klimaundsedimente. geowissenschaften.uni-mainz.de/projekt-lueneburg. Accessed 2 Jan 2021

Sirocko F, Szeder T, Seelos C, Lehné R, Rein B, Schneider WM, Dimke M (2002) Young tectonic and halokinetic movements in 
the North-German-Basin: its effect on formation of modern rivers and surface morphology. Neth J Geosci 81:431-441. https:// doi.org/10.1017/S0016774600022708

Sirocko F, Reicherter K, Lehné R, Hübscher C, Winsemann J, Stackebrandt W (2008) Glaciation, salt and the present landscape. In: Littke R, Bayer U, Gajewski D, Nelskamp S (eds) Dynamics of complex intracontinental basins, 1st edn. Springer, Berlin, pp 233-246

Stein R (1985) Rapid grain-size analyses of clay and silt fraction by Sedigraph 5000D: comparison with Counter and Atterberg methods. J Sediment Petrol 55:590-615. https://doi.org/10. 2110/55.4.590

Steinitz G, Begin ZB, Gazit-Yaari N (2003) Statistically significant relation between radon flux and weak earthquakes in the Dead Sea rift valley. Geology 31(6):505-508. https://doi.org/10.1130/ 0091-7613(2003)031\%3c0505:SSRBRF\%3e2.0.CO;2

Strong KP, Levins DM (1982) Effect of moisture content on radon emanation from uranium ore and tailings. Health Phys 42(1):2732. https://doi.org/10.1097/00004032-198201000-00003

Tanner AB (1964) Radon migration in the ground: a review. In: Adams JAS, Lowder WM (eds) Natural radiation environment. University of Chicago Press, Chicago, pp 161-190

Tanner AB (1980) Radon migration in the ground: a supplementary review. In: Gesell, Lowder WM (ed) Proceedings of the symposium on third natural radiation environment 1, Houston, pp 5-56

Tareen ADK, Rafique M, Basharat M (2019) Study of diurnal and seasonal variations in the time series data of soil ${ }^{222} \mathrm{Rn}$ gas. Int J Environ Anal Chem. https://doi.org/10.1080/03067319. 2019.1666834

Tatzber M, Stemmer M, Spiegel H, Katzlberger C, Haberhauer G, Gerzabek MH (2007) An alternative method to measure carbonate in soils by FT-IR spectroscopy. Environ Chem Lett 5:9-12. https://doi.org/10.1007/s10311-006-0079-5
Tuccimei P, Soligo M (2008) Correction for $\mathrm{CO}_{2}$ interference in soil radon flux measurements. Radiat Meas 43(1):102-105. https:// doi.org/10.1016/j.radmeas.2007.05.056

Turekian KK, Graustein WC (2003) Natural radionuclides in the atmosphere. In: Keeling RF, Holland HD, Turekian KK (ed) Treatise on geochemistry. The atmosphere, vol 4. Elsevier, Amsterdam, pp 262-279. https://doi.org/10.1016/B0-08-043751-6/04042-1

UNSCEAR (1982) Ionizing radiation: Sources and biological effects. UNSCEAR 1982 Report, New York

Wiederhold H, Agster G, Binot F, Kirsch R (2003) Geophysical investigations on the connection between salt structures and aquifers in Schleswig-Holstein. In: Mares S, Pospisil L (ed) Proceedings 9th meeting environmental and engineering geophysics: P-065, Prague. https://doi.org/10.3997/2214-4609.201414638

Winkler R, Ruckerbauer F, Bunzl K (2001) Radon concentration in soil gas: a comparison of the variability resulting from different methods, spatial heterogeneity and seasonal fluctuations. Sci Total Environ 272(1-3):273-282. https://doi.org/10.1016/S00489697(01)00704-5

Woith H (2015) Radon earthquake precursor: a short review. Eur Phys J Spec Top 224:611-627. https://doi.org/10.1140/epjst/ e2015-02395-9

Yan R, Woith H, Wang R, Wang G (2017) Decadal radon cycles in a hot spring. Sci Rep 7:1-12. https://doi.org/10.1038/ s41598-017-12441-0

Yang J, Busen H, Scherb H, Hürkamp K, Guo Q, Tschiersch J (2019) Modeling of radon exhalation from soil influenced by environmental parameters. Sci Total Environ 656:1304-1311. https://doi. org/10.1016/j.scitotenv.2018.11.464 